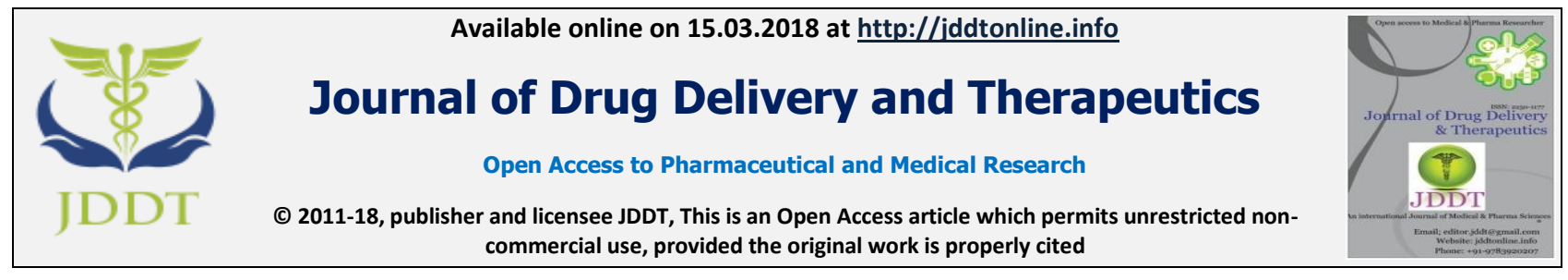

Open $\odot$ Access

Research Article

\title{
DESIGN AND CHARACTERIZATION OF SUSTAINED RELEASE MATRIX TABLETS OF METFORMIN HYDROCHLORIDE USING COMBINATION OF HYDROPHILIC POL YMERS
}

\author{
Anjita Singh*, Devendra Singh Rajput, Awankar Akshay Gopalrao, Deepak Chauhaan, Rajmani Mafidar, \\ Mithun Bhowmick, Jagdish Rathi, Rahul Mathur
}

NRI Institute of Pharmaceutical Sciences, Bhopal, M.P., India

\section{ABSTRACT}

Sustained release system is types of modified drug delivery system that can be used as an alternative to conventional system. Among different dosage forms, matrix tablets are widely accepted for oral sustained release Metformin hydrochloride has relatively short plasma half-life, low absolute bioavailability. The need for the administration two to three times a day when larger doses are required can decrease patient compliance. Sustained release formulation that would maintain plasma level for 8-12 h might be sufficient for daily dosing of metformin. Sustained release products are needed for metformin to prolong its duration of action and to improve patient compliances. They are capable of reducing the dose intake, minimize the blood level oscillation dose related adverse effect and cost thus improves the patient compliance in the therapeutic management of diabetes. The Metformin hydrochloride matrix Sustained release tablets were prepared using different hydrophilic polymers in various proportions as release retarding agent to prolong the drug release and to improve the patience compliance. The tablets were evaluated for various tests like hardness, friability, disintegration and in-vitro dissolution studies.

Keywords: Matrix Tablets, Metformin hydrochloride, Hardness, Friability, Disintegration and in-vitro dissolution studies

Article Info: Received 9 Jan, 2018; Review Completed 3 March, 2018; Accepted 3 March, 2018; Available online 15 March, 2018

Cite this article as:

Singh A, Rajput DS, Gopalrao AA, Chauhaan D, Mafidar R, Bhowmick M, Rathi J, Mathur R, Design and characterization of sustained release matrix tablets of metformin hydrochloride using combination of hydrophilic polymers, Journal of Drug Delivery and Therapeutics. 2018; 8(2):96-101

DOI: http://dx.doi.org/10.22270/jddt.v8i2.1672

*Add ress for Correspondence: Anjita Singh, NRI Institute of Pharmaceutical Sciences, Bhopal, M.P., India

\section{INTRODUCTION}

Sustained release system is types of modified drug delivery system that can be used as an alternative to conventional system. Among different dosage forms, matrix tablets are widely accepted for oral sustained release1. Sustained release systems have benefits like patient compliance, avoidance of multiple dosing, cost effectiveness, flexibility, increased plasma drug concentration, reduction of side effects; broad regulatory acceptance and they overcome the problems associated with conventional drug delivery system. Metformin hydrochloride an orally administered biguanide, which is widely used in the management of and the type -II diabetes, is an oral anti-hyperglycemic agent, shows incomplete absorption from the gastrointestinal tract and the absolute bioavailability is $50-60 \%$ with relatively short plasma half-life of $1.5-4.5 \mathrm{~h}$. The aim of this work is to prepare matrix tablets containing Metformin hydrochloride, as a model drug, using different polymers and evaluate its release characteristics. ${ }^{1-6}$

\section{MATERIALS AND METHODS}

\section{MATERIALS}

Metformin $\mathrm{HCl}$ powder was a gift from USV Ltd, Mumbai, India. Microcrystalline cellulose, talc, magnesium stearate, polymers such as HPMC and sodium alginate were purchased from S. D. Fine Chem. Labs. (Mumbai, India). All other ingredients used throughout the study were of analytical grade and were used as received. 


\section{METHODS}

\section{Formulation of sustained release tablet ${ }^{7-9}$}

Sustained Release Tablets of Metformin HCL with other excipients were prepared by direct compression. The weight of Metformin HCL was kept constant in all the prepared tablets at $400 \mathrm{mg} /$ tablet. Different ratio grades of HPMC \& SODIUM ALGINATE were chosen as polymeric materials. Micro crystalline cellulose (MCC) was selected as tablet diluent for increasing the compressibility and flowability of the ingredients as well as to maintain the tablets at constant weight of $400 \mathrm{mg}$.
Magnesium stearate was used as a lubricant at concentration of $2 \%$ by weight of tablet. To make powder mixtures, the drug, polymer and MCC were thoroughly mixed for 30 min by means of pestle and mortar. This powder mixture was then lubricated with magnesium stearate then compressed into tablets in 6 $\mathrm{mm}$ rotary tablet punching machine. The force of compression was adjusted so that hardness of all the prepared tablets ranges from $5.5-6.5 \mathrm{~kg} / \mathrm{cm}$. The detailed compositions of the prepared matrix tablets formulations are given in (Table no.1)

Table 1: Formulation of sustained released tablet having ratio 1:2

\begin{tabular}{|c|c|c|}
\hline S.No. & Ingredient & $\begin{array}{c}\text { Formulation for } \\
\text { polymer ratio 1:2 }\end{array}$ \\
\hline 1. & Metformin HCL & $300 \mathrm{mg}$ \\
\hline 2. & Talc & $10 \mathrm{mg}$ \\
\hline 3. & Hydroxypropyl methylcellulose (HPMC) & $10 \mathrm{mg}$ \\
\hline 4. & Sodium alginate & $20 \mathrm{mg}$ \\
\hline 5. & Magnesium stearate & $10 \mathrm{mg}$ \\
\hline 6. & Micro crystalline cellulose (M.C.C.) & $50 \mathrm{mg}$ \\
\hline
\end{tabular}

Table 2: Formulation of sustained released tablet having ratio 2:1

\begin{tabular}{|c|c|c|}
\hline S.No. & INGREDIENT & FORMULATION FOR POLYMER RATIO 2:1 \\
\hline 1. & Metformin HCL & $300 \mathrm{mg}$ \\
\hline 2. & Talc & $10 \mathrm{mg}$ \\
\hline 3. & Hydroxypropyl methylcellulose (HPMC) & $20 \mathrm{mg}$ \\
\hline 4. & Sodium alginate & $10 \mathrm{mg}$ \\
\hline 5. & Magnesium stearate & $10 \mathrm{mg}$ \\
\hline 6. & Micro crystalline cellulose (M.C.C.) & $50 \mathrm{mg}$ \\
\hline
\end{tabular}

\section{1) Angle of Repose ${ }^{10,11}$}

The angle of repose was determined by fixed funnel method. A funnel was kept vertically in a stand at a specified height above a paper place on a horizontal surface. The funnel was closed was closed and granules was filled in funnel. Then funnel was opened to release the granules on the paper to form a smooth conical heap. The height and radius of heap was measured and the angle of repose was calculated by using the following formula.

$$
\theta=\tan ^{-1} h / r
$$

Where $\Theta=$ Angle of repose, $h=$ height of heap and $r=$ radius

Table 3: Relationship between Angle of Repose ( $\theta$ ) and flow properties

\begin{tabular}{|c|c|}
\hline $\begin{array}{c}\text { Angle of repose }(\Theta) \\
\text { (Degrees) }\end{array}$ & FLOW \\
\hline$<25$ & Excellent \\
\hline $25-30$ & Good \\
\hline $30-40$ & Passable \\
\hline$>40$ & Very poor \\
\hline
\end{tabular}

2) Bulk Density ${ }^{10,11}$

A known amount of granules was transferred into a 25$\mathrm{ml}$ measuring cylindrical carefully level the granules without compacting and measure the bulk volume. The bulk density was determined by using the formula:

Bulk Density $=$ Weight of granules $/$ bulk volume

\section{3) Tapped Density ${ }^{10,11}$}

Tapped density was determined by digital bulk density apparatus. A known amount of granules was transferred into the measuring cylinder and tapped upto 100 times and measure the tapped volume. The tapped density was determined by using the formula:

Tapped Density $=$ Weight of granules / tapped volume

\section{4) Compressibility Index ${ }^{10,11}$}

Compressibility Index was determined by the following formula:

\section{Compressibility Index =}

[Tapped density - Bulk density / Tapped density] 100 
Table 4: Relationship between Compressibility Index and flow properties

\begin{tabular}{|c|c|}
\hline $\begin{array}{c}\text { \% CARR'S COMPRESSIBILTY } \\
\text { INDEX }\end{array}$ & FLOW \\
\hline $5-15$ & Excellent \\
\hline $12-16$ & Good \\
\hline $18-21$ & Fair to passable \\
\hline $23-35$ & Poor \\
\hline $33-38$ & Very poor \\
\hline$>40$ & Very \\
\hline
\end{tabular}

\section{5) Hausner's Ratio ${ }^{10,11}$}

Hausner's ratio was determined by following formula:

\section{Hausner's ratio $=$ Tapped density / Bulk density}

\section{6)}

$$
\text { Hardness }^{10,11}
$$

In the measurement of hardness, the crushing strength of the tablets is measured. It gives the tablets breaking force and the strength of the physical tablets are represented by the hardness. Hardness was measured using a Pfizer hardness tester. Hardness to be measured of ten tablets. The hardness were measured in newton. The average hardness, relative standard deviation, standard deviations were reported. The hardness of the tablets were measured during start and between the compression.

\section{7) Weight variation test ${ }^{10,11}$}

To study weight variation, 20 tablets of each formulation were collected randomly during compression and weighed using an electronic balance to obtain average weight of each tablets. Also, the individual tablet was weighted.

Limit: Weight of individual tablet should be in the limit of average weight $\pm 5 \%$

\section{8) Friability ${ }^{12-14}$}

The test was carried out using ROCHE FRIABILATOR. Ten tablets were taken and carefully dedusted prior to testing the tablets were weighed accurately, and placed the tablets in the drum. The drum was allowed to be rotated 100 times, and after that the tablets were removed. Removed loose dust form the tablets as before, and weighed accurately.
The $\%$ loss was determined by using following formula:

$$
\% \text { Weightloss }=\frac{\text { Initial Weight }- \text { Final Weight }}{\text { Initial Weight }}
$$

A maximum loss of mass not greater than $1.0 \%$ is considered acceptable.

\section{9) Uniformity of drug content ${ }^{12-14}$}

Five tablets were weighed individually and powdered. The powdered equivalent to average weight of tablet was weighed and drug was extracted in $0.1 \mathrm{~N} \mathrm{HCL}$. Undissolved material was filtered out. Filtrate was analysed in UV spectrometer at $237 \mathrm{~nm}$ after suitable dilution. Absorbence value was substituted in the equation of standard curve of Metformin HCL determined earlier.

Drug content was calculated by following formula.

$$
\text { DrugContent }=\frac{\text { Actual drug content }}{\text { Theoritical drug content }} \times 100
$$

\section{In-vitro Dissolution Studies ${ }^{12-16}$}

In-vitro drug release study of tablets was performed in USP dissolution apparatus Type -2 (Paddle). The dissolution test was performed using $900 \mathrm{ml}$ of phosphate buffer $6.8 \mathrm{ph}$. at $37 \pm 0.0 .5^{\circ} \mathrm{C}$ with $50 \mathrm{rpm}$. A sample $(5 \mathrm{ml})$ was withdrawn from the dissolution apparatus and volume equivalent to the amount of sample withdrawn was replaced with fresh dissolution dissolution medium. The sample were filtered and diluted to suitable concentration with phosphate buffer $6.8 \mathrm{ph}$. Absorbances of these solutions were measured at $237 \mathrm{~nm}$ using a UV spectrophotometer. Cumulative percentage drug dose was calculated using an equation obtained from standard curve.

\section{1) \\ In-Vitro Drug Release Kinetic Study}

Kinetic model had described drug dissolution from solid dosage form were the dissolved amount of drug is a function of test time. In order to study the exact mechanism of drug release from the tablet, drug release data was analyzed according to zero order, first order, Higuchi square root, korsemeyer, Peppas model. The regression coefficient $R^{2}$ value nearer to 1 indicating the model fitting of the release mechanism.

\section{RESULT AND DISCUSSION}

1) Melting Point: The melting point of experimental drug shown in table.

Table 5: Melting point of drug

\begin{tabular}{|l|l|l|l|}
\hline TEST & DRUG & SPECIFICATION & OBERVATION \\
\hline Melting point & Metformin HCL & $222-226^{0} \mathrm{c}$ & $223-227^{\mathrm{c}}$ \\
\hline
\end{tabular}

\section{2) Determination of Wavelength Of Maximum Absorbance}

The wavelength of maximum absorbence $(\lambda \max )$ in $0.1 \mathrm{~N} \mathrm{HCL}$ was found to be $235 \mathrm{~nm}$ and the graph is shown in figure. 


\section{3) Solubility Of Drug}

The solubility of drug in different solvent in shown in table.

Table 6: Solubility of drug in different solvent

\begin{tabular}{|c|c|c|}
\hline S.No. & Solvent & Solubility \\
\hline 1 & Distilled Water & Freely soluble \\
\hline 2 & 0.1 N HCL & Soluble \\
\hline 3 & Ethanol (95\%) & Slightly soluble \\
\hline 4 & Methylene chloride & Practically insoluble \\
\hline 5 & Acetone & Practically insoluble \\
\hline
\end{tabular}

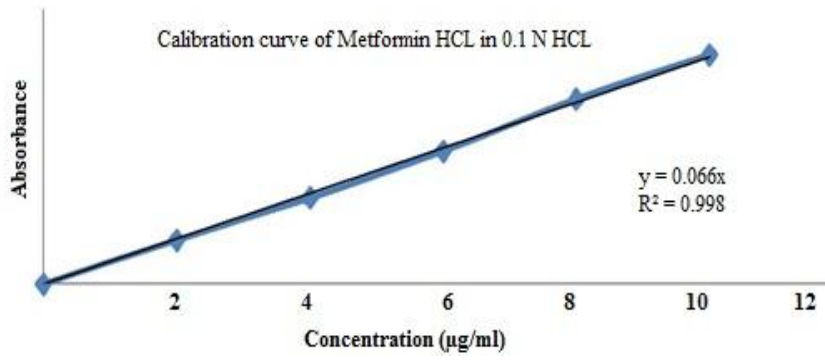

Figure 1: Calibration curve of Metformin on $0.01 \mathrm{~N}$ HCL

5) Evaluation of precompression parameters

Table 7: Evaluation of precompression parameters

\begin{tabular}{|c|c|c|}
\hline \multirow{2}{*}{ Parameters } & \multicolumn{2}{|c|}{ Hydrophilic Formulations } \\
\cline { 2 - 3 } & Polymer ratio 1:2 & Polymer Ratio 2:1 \\
\hline Carss's Index $(\%)(\mathrm{n}=3)$ & $5.00 \pm 0.02$ & $2.44 \pm 0.06$ \\
\hline Hausner'sRatio(n=3) & $1.052 \pm 0.06$ & $1.025 \pm 0.08$ \\
\hline Angle of Repose $(\mathrm{n}=3)$ & $33.69 \pm 0.09$ & $35.31 \pm 0.04$ \\
\hline Length(mm)(n=20) & $15.088 \pm 0.03$ & $15.136 \pm 0.01$ \\
\hline Hardness $(\mathrm{kP})(\mathrm{n}=20)$ & $33.2 \pm 0.01$ & $401.8 \pm 0.02$ \\
\hline Weight $(\mathrm{mg})(\mathrm{n}=20)$ & $399.4 \pm 0.04$ & $8.152 \pm 0.01$ \\
\hline Thickness $(\mathrm{mm})(\mathrm{n}=20)$ & $8.096 \pm 0.06$ & $0.107 \pm 0.06$ \\
\hline Friability $(\%)(\mathrm{n}=10)$ & $0.0197 \pm 0.03$ & $100.315 \pm 0.04$ \\
\hline ContentUniformity $(\%)(\mathrm{n}=20)$ & $100.268 \pm 0.05$ & \\
\hline
\end{tabular}

\section{Evaluation of post compression parameter}

The results of post compression parameters such as hardness, Friability, Weight variation and Drug content uniformity are shown in table.

Table 8: Result of post compression parameters of formulation

\begin{tabular}{|c|c|c|c|c|}
\hline Batches & Hardness $\left(\mathrm{kg} / \mathrm{cm}^{2}\right)$ & Friability (\%) & Weight Variation & $\begin{array}{c}\text { Drug Content } \\
\text { Uniformity }\end{array}$ \\
\hline $\mathrm{F} 1$ & 12.4 & 0.70 & Passes & 90.12 \\
\hline $\mathrm{F} 2$ & 14.52 & 0.66 & Passes & 92.65 \\
\hline F3 & 15 & 0.62 & Passes & 96.15 \\
\hline
\end{tabular}

1) In Vitro Dissolution Study:The results obtaining in vitro release studies were plotted Cumulative \% release against time. These results indicated that the release rate was limited by the drug particles dissolution rate and erosin of the different polymer ratio. 


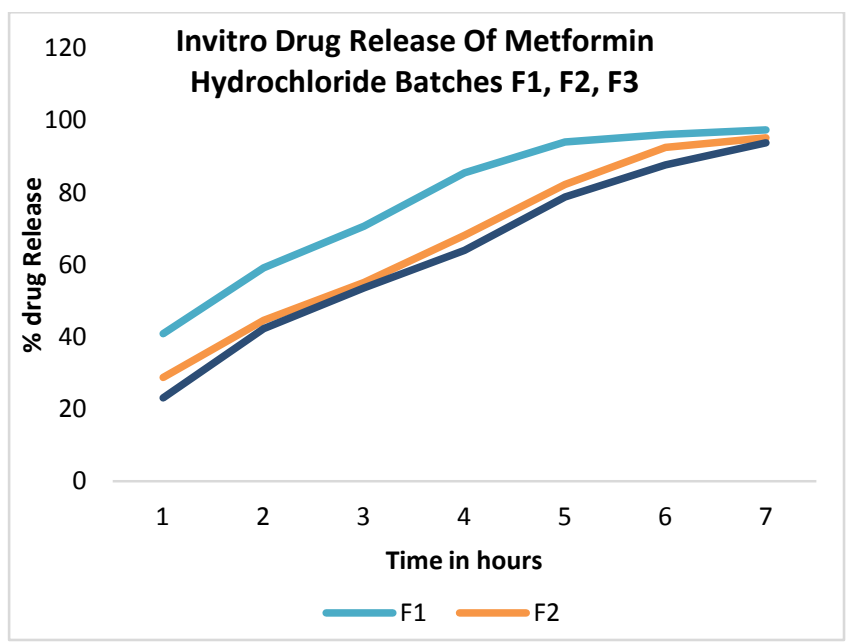

Figure 2: Dissolution Profile of Formulations

Table 9: Release kinetic Study

\begin{tabular}{|c|c|c|c|}
\hline \multirow{3}{*}{$\begin{array}{c}\text { Time } \\
\text { (hrs. })\end{array}$} & \multicolumn{3}{|c|}{ \% Drug Release } \\
\cline { 2 - 4 } & F1 & Batch No. \\
\cline { 2 - 4 } & Marketed Drug & Polymer Ratio 2:1 & Polymer Ratio 1:2 \\
\cline { 2 - 4 } & 40.85 & 28.79 & 23.14 \\
\hline 1 & 59.21 & 44.63 & 42.25 \\
\hline 2 & 70.68 & 55.16 & 53.67 \\
\hline 3 & 85.53 & 68.25 & 64.03 \\
\hline 4 & 94.12 & 82.32 & 78.89 \\
\hline 6 & 96.23 & 92.57 & 87.76 \\
\hline 8 & 97.45 & 95.27 & 93.86 \\
\hline 10 & & & F3 \\
\hline
\end{tabular}

2)

\section{Kinetic Release Study}

Kinetics of Metformin Hydrochloride sustained released formulation:

The optimized batch $\mathrm{F}_{6}$ was subjected to graphical treatment to assess the kinetic of drug release from 1:2 polymer ratio tablet. The optimized formulation F6 was subjected to Zero order, first order, Hixson-Crowell,
Higuchi and Korsmeyer-Peppas model to study the in vitro kinetic release mechanism.

From, in vitro kinetic release mechanism study it was found that the drug released kinetic of the sustained release formulation of optimized batch F6 follow diffusion mechanism for drug release from the 1:2 polymer ratio tablet.

Table 10: Zero order kinetic Model

\begin{tabular}{|c|c|c|}
\hline S. No. & Time in hour & Cum.\% Drug release \\
\hline 1. & 0.5 & 11.6 \\
\hline 2. & 1 & 26.13 \\
\hline 3. & 2 & 42.26 \\
\hline 4. & 3 & 53.77 \\
\hline 5. & 4 & 64.02 \\
\hline 6. & 6 & 79.31 \\
\hline 7. & 8 & 87.56 \\
\hline 8. & 10 & 93.68 \\
\hline
\end{tabular}


Table 11: First order kinetic Model

\begin{tabular}{|c|c|r|}
\hline & Time in hour & $\begin{array}{c}\text { Log Cum.\% Drug } \\
\text { retained }\end{array}$ \\
\hline 1. & 0.5 & 1.946 \\
\hline 2. & 1 & 1.868 \\
\hline 3. & 2 & 1.761 \\
\hline 4. & 3 & 1.664 \\
\hline 5. & 4 & 1.556 \\
\hline 6. & 6 & 1.315 \\
\hline 7. & 8 & 1.094 \\
\hline 8. & 10 & 0.801 \\
\hline
\end{tabular}

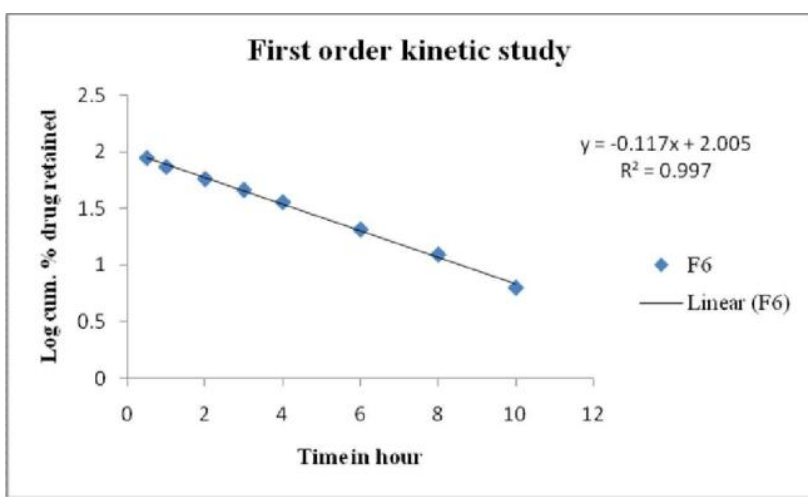

Figure 3: First order kinetic Model

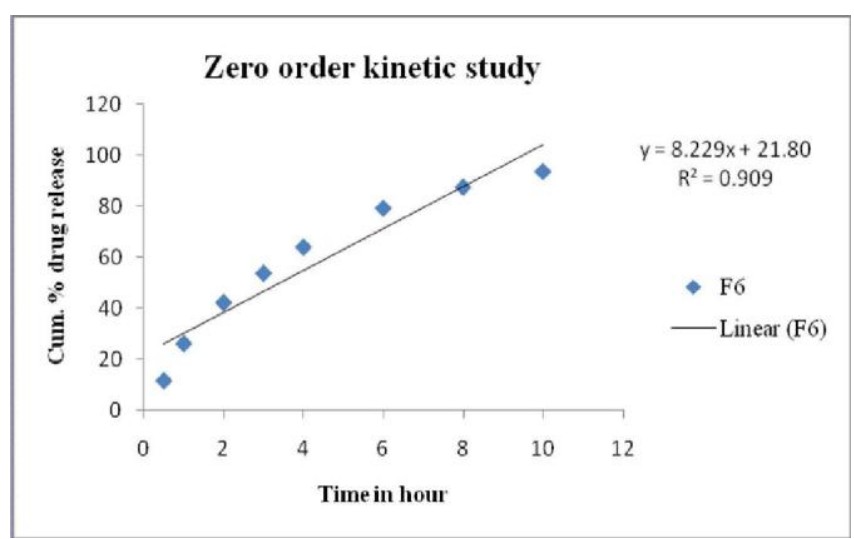

Figure 4: Zero order kinetic Model

\section{CONCLUSION}

The present work deals with the aim to formulate and evaluate the sustained release tablet of Metformin HCL. From results obtained, it was concluded that the formulation of sustained release tablet of Metformin HCL containing hydrophilic polymers HPMC and sodium alginate were capable of exhibiting sustained release properties They are capable of reducing the does intake minimize the blood level oscillation does related adverse effect and cost thus improves the patient compliance in the therapeutic management of diabetes.

\section{REFERENCES}

1. Stith BJ, Goalstone ML, Espinoza R, Mossel C, Roberts D, Wiernsperger $\mathrm{N}$. The antidiabetic drug metformin elevates receptor tyrosine kinase activity and inositol 1, 4, 5triphosphate mass in Xenopus oocytes. Endocrinology. 1996; 137:2990-9. [PubMed: 8770923]

2. Wiley A. Insulin and oral hypoglycemic drugs. In: Williams DA, Lemke TL, editors. Foyes Principle of medicinal chemistry. New York: Lippincott Williams and Wilkins; 2002. pp. 641-8.

3. Martindale SC. London: The Pharmaceutical Press; 2002. The Complete Drug Reference.

4. Dunn CJ, Peters DH, Metformin A review of its pharmacological properties and therapeutic use in noninsulindependent diabetes mellitus Drugs, 1995, 49, 5, 721749.

5. Dunn CJ, Peters DH. Metformin: A review of its pharmacological properties and therapeutic use in noninsulindependent diabetes mellitus. Drugs. 1995; 49:721-49. [PubMed: 7601013]

6. Defang O, Shufang N, Wei L. In vitro and in vivo evaluation of two extended Release preparations of combination metformin and glipizide. Drug Dev Ind Pharm. 2005; 31:677-85. [PubMed: 16207615]

7. Salsa T, Veiga F, Pina ME. Oral control release dosge form I. Cellulose ether polymer in hydrophilic matrices. Drug Dev Ind Pharm. 1997; 23:929-38.

8. Chien YW. New York: Marcel Dekker; 1992. Novel drug delivery systems; pp. 1-43.

9. Mehta KA, Kislaloglu MS, Phuapradit W, Malik AW, Shah NH. Release performance of a poorly soluble drug from a

novel Eudragit-based multiunite erosion matrix. Int J Pharm Sci. 2001; 213:7-12.

10. Kibbe AH. Washington DC: American Pharmaceutical Association; 2000. Handbook of pharmaceutical excipients.

11. Sanchez L, Teresa F, Fernandez A, Alvarez F, Rabasco A, Mura P. Development of sustained release matrix tablets of didanosine containing methacrylic and ethylcellulose polymers. Int J Pharm Sci. 2002; 234:213-21.

12. Reddy KR, Mutalik S, Reddy S. Once-daily sustained-release matrix tablets of Nicorandil: Formulation and in vitro evaluation. AAPS PharmSciTech. 2003; 61:4. [PMCID: PMC2750654]

13. Rodriguez L, Caputo O, Cini M, Cavallari C, Grecchi R. In vitro release of theophylline from directly compressed matrices containing methacrylic acid copolymers and/or dicalcium posphate dihydrate. II Farmaco. 1993; 48:1597604.

14. Rao VM, Engh K, Qiu Y. Design of $\mathrm{pH}$-independent controlled release matrix tablets for acidic drugs. Int J Pharm Sci. 2003; 252:81-6.

15. Gohel MC, Patel TP, Bariya SH. Studies in preparation and evaluation of $\mathrm{pH}$ independent sustained release matrix tablets of verapamil $\mathrm{HCl}$ using directly compressible Eudragits. Pharm Dev Technol. 2003; 8:323-33. [PubMed: 14601957]

16. Liu J, Zhang F, McGinity JW. Properties of lipophilic matrix tablets containing phenylpropanolamine hydrochloride prepared by hot-melt extrusion. Eur J Pharm Biopharm. 2001; 52:181-90. [PubMed: 11522484] release. Pharm Dev Technol. 1997; 2:161-70. [PubMed: 9552442] 